DOI: https://doi.org/10.32839/2304-5809/2020-12-88-14

УДК 821.161.2:81'25'373

Куліш В.С., Гарах О.М.

Сумський державний університет

\title{
ТРУДНОЩІ ПЕРЕКЛАДУ КУЛЬТУРНО МАРКОВАНОЇ ЛЕКСИКИ
}

Анотація. Проблеми значення культурно маркованої лексики є важливим елементом міжкультурних та міжмовних контактів. У статті відтворюються питання, пов'язані зі способами перекладу культурно маркованої лексики, особлива увага приділяеться основним труднощам під час перекладу. Вивчення способів передачі реалій при перекладі визначається зростаючим інтересом до дослідження мов на різних рівнях, тенденцією до вивчення взаємозв'язку мови і культури, так як саме в культурно маркованій лексиці відображається специфіка мислення кожного народу. Сучасні літературні твори містять безліч слів, описів традищій, звичаїв і явищ, незрозумілих носіям інших культур. Переклад текстів, що містять такого роду одиниці викликає ряд проблем. Так, переклад культурно маркованої лексики ускладнений тим, що редерент реалії може відсутні в мові, що, або ж бути дещо відмінним від мови оригіналу. Актуальність даної статті обумовлена недостатнім вивченням ролі культурно маркованої лексики при перекладі, що часто призводить до зниження цінності сприйняття перекладеного тексту. При перекладі текстів важливо зберігати культурно-історичну своєрідність оригіналу. У тому випадку, якщо текст, що перекладається відноситься до певної епохи, написаний мовою, що нині не вживаеться, і співвідноситься з архаїчними культурними традиціями, то перекладач повинен володіти не тільки винятковими лінгвістичними навичками, але і великими фрілологічними та історичними знаннями. В цьому випадку для перекладача незамінними будуть не тільки базові знання теорії перекладу, а й приклади практичної реалізації тих чи інших методів, шляхів передачі реалій на іншу мову. Адже читач повинен не замислюватися в процесі читання про точність значення того чи іншого слова, а сприймати значення як фракт. У статті дано теоретичне обгрунтування культурно маркованої лексики, розроблено класифікацію культурно маркованої лексики за різними критеріями, проаналізовано основні прагматичні фрункції національно маркованих лексичних одиниць, запропоновано основні шляхи розв'язання проблем адекватного відтворення культурно маркованої лексики при перекладі текстів українською мовою. Для передачі специфічної лексики в практиці перекладу використовується безліч способів і прийомів, які стали результатом багатовікових мовних контактів і які призвели до накопичення знань про лексико-граматичні відповідності. В цілому, можна зробити висновок, що при передачі національно маркованої лексики найчастіше використовуеться прийом калькування, що допомагае адекватно передати текст мовою оригіналу без смислових спотворень; зберегти національний і історичний колорит; зробити прагматичний та естетичний вплив на реципієнта.

Ключові слова:культурно маркована лексика, стратегія перекладу, форенізація, доместикація, транскрипція, транслітерація, калькування, описовий, наближений, гіпонімічний та контекстуальний переклад.

Kulish Vladyslava, Harakh Olena

Sumy State University

\section{DIFFICULTIES IN TRANSLATING CULTURALLY MARKED VOCABULARY}

Summary. Problems of the meaning of culturally marked vocabulary are an important element of intercultural and interlingual contacts. The article reproduces the issues related to the methods of translation of culturally marked vocabulary, special attention is paid to the main difficulties in translation. The study of ways of conveying realities in translation is determined by the growing interest in the study of languages at different levels, the tendency to study the relationship between language and culture, as it is in the culturally marked vocabulary reflects the specifics of each nation. Modern literary works contain many words, descriptions of traditions, customs and phenomena, incomprehensible to the bearers of other cultures. Translation of texts containing this type of unit causes a number of problems. Thus, the translation of culturally marked vocabulary is complicated by the fact that the referent of reality may be absent in the language that is, or be somewhat different from the language of the original. The relevance of this article is due to insufficient study of the role of culturally marked vocabulary in translation, which often leads to a decrease in the value of perception of the translated text. When translating texts, it is important to preserve the cultural and historical originality of the original. In that case, if the translated text belongs to a certain era, written in a language not used today, and correlates with archaic cultural traditions, the translator must have not only exceptional linguistic skills, but also extensive philological and historical knowledge. In this case, the translator will be indispensable not only basic knowledge of translation theory, but also examples of practical implementation of certain methods, ways of transmitting realities to another language. After all, the reader should not think in the process of reading about the accuracy of the meaning of a word, and perceive the meaning as a fact. The article gives a theoretical substantiation of culturally marked vocabulary, develops a classification of culturally marked vocabulary according to various criteria, analyzes the main pragmatic functions of nationally marked lexical items, offers basic ways to solve problems of adequate reproduction of culturally marked vocabulary in Ukrainian translation. Many methods and techniques are used to transfer specific vocabulary in the practice of translation, which are the result of centuries of linguistic contacts and which have led to the accumulation of knowledge about lexical and grammatical correspondences. In general, we can conclude that the transmission of nationally marked vocabulary often uses the technique of tracing, which helps to adequately convey the text in the original language without semantic distortions; preserve the national and historical color; make a pragmatic and aesthetic impact on the recipient.

Keywords: culturally marked vocabulary, translation strategy, foreignization, domestication, transcription, transliteration, calque, descriptive, approximate, hyponymic and contextual translation.

(C) Куліш B.С., Гарах O.М., 2020 
$\Pi$ остановка проблеми. Культура кожного народу має свою унікальність, яка відображається у мові. Поряд із загальнолюдськими цінностями та поняттями, існують такі, які властиві одній певній культурі, і яких немає в культурах інших народів. Дане явище викликає особливий інтерес з позиції перекладу, так як перекладачі $є$ посередниками в процесі міжкультурної комунікації. Вивчення взаємозв'язку мови і культури є важливим напрямом сучасної лінгвістики. Це пояснюеться постійно зростаючими практичними потребами інтенсивної міжкультурної комунікації, а також недостатньою кількістю загальнотеоретичних досліджень. Найбільший інтерес для вивчення представляе так звана культурно маркована лексика, за допомогою якої можна найбільш яскраво розглянути механізм передачі культури через лексику мови, що вивчаеться.

Актуальність вивчення даної теми зумовлена недостатнім вивченням проблеми перекладу культурно маркованої лексики та необхідністю розширити фонові знання про способи адекватної передачі національних слів рідною мовою.

Аналіз останніх досліджень і публікацій. Питання перекладу культурно маркованої лексики цікавлять різних вчених, серед яких В. Н. Комісаров, Л. К. Латишев, С. Влахов, С. Флорін і т.д. Дослідженням культурно маркованої лексики та особливостями їхньої класифрікащії займалися такі мовознавці, як С. М. Верещагін, I. О. Голубовська, Р. П. Зорівчак, В. Г. Костомаров, М. П. Кочерган, О. С. Снитко, Г. Д. Томахін, Н. П. Хіль, Дж. Ліон, П. Ньюмарк та ін. Помітними є й наукові доробки Я. В. Бойко, М. В. Бондар, Г. Добросклонської, А. В. Зорницького, Т. А. Іванкової, Ю. В. Ковалюк, В. В. Ощепкової, М. Б. Сизоненко, О. О. Татьянченко, Т. Ю. Тупищі, Н. П. Ясиненко, М. Г. Яшиної.

Виділення раніше не вирішеної проблеми. До сьогоднішнього часу не було виділено єдиного способу перекладу культурно маркованої лексики для досягення повної адекватності при передачі іншомовних слів національного характеру. Оскільки, сприйняття культури іншого народу відбувається через призму своєї культури, що і призводить до виникнення нерозуміння, а часом і заперечення чужих реалій життя. Таким чином, питання перекладу культурно маркованої лексики є нагальним сьогодні і потребує ретельного дослідження.

Формулювання цілей статті: розробити класифікацію культурно маркованої лексики, проаналізувати основні прагматичні фрунції національно маркованих одиниць, визначити найбільш поширені труднощі при перекладі культурно маркованої лексики, а також основні способи їі перекладу.

Об'єктом даної роботи виступає культурно маркована лексика.

Предмет дослідження - способи передачі культурно маркованої лексики українською мовою.

Виклад основного матеріалу. Мова знаходиться в тісному взаємозв'язку 3 життям суспільства і відображає його соціальне, економічне і політичне життя. У міру розвитку суспільства мова збагачуеться новими поняттями, термінами, кожна окремо взята соціальна система відрізняеться своїми особливостями розвитку, які миттево відо- бражаються на словниковому складі мови. Можна виявити численні відмінності при порівнянні лексики декількох мов. Слова, що не мають відповідника в іншій мові при перекладі називають культурно маркованою лексикою. Взаємозв'язок культур ускладнюеться внаслідок наявності безеквівалентної лексики, яка має різний характер, причини виникнення та вимагає пояснення.

Термін «культурно маркована лексика» 3'явився в 1980-х роках. С. М. Верещагін і В. Г. Костомаров визначають цю групу слів як слова, які несуть в собі соціокультурну інформацію [10, с. 56]. Дослідники у своїх роботах застосовують такі синонімічні терміни до культурно маркованої лексики як, «лексичні одиниці з національно культурним компонентом», «безеквівалентна лексика», «національно маркована лексика", "національно забарвлені лексичні одиниці», «соціокультурна маркована лексика", "культурно специфічна мовна одиниця». У сучасному мовознавстві немає єдиної класифікації культурно маркованих одиниць, а існуючі класифікації засновані на тимчасових, семантичних, граматичних, місцевих, фронетичних та інших ознаках.

Поняття «стратегія перекладу» досить широко використовується в сорері лінгвістики та перекладознавства [5, с. 81]. Перекладацька стратегія алгоритм дій, техніка, прийом, метод, спосіб або трансформація, що застосовуеться до тексту перекладу. Першим, хто згадав термін «стратегія перекладу» був німецький профресор прикладної лінгвістики Ханс П. Крінгс. Стратегії перекладу, на його думку, направляють перекладача i $є$ невід'ємними компонентами в процесі перекладу. Тлумачення перекладацької стратегії також можна простежити в роботі німецького фрілософра $\Phi$. Шлейермахера, який стверджував, що існують два шляхи перекладу: перенесення читача до автора, або перенесення автора до читача [13, с. 468-488]. Л. Венуті розглядає співвідношення двох стратегій, називаючи їx "domestication" («доместикація») i "foreignization" («форенізація»). Згідно Л. Венуті, доместикація є якоюсь адаптацією іншомовного тексту до культурних цінностей цільової мови, а фроренізація, навпаки, полягає в яскравому вираженні цих культурних переваг для підкреслення лінгвістичних та національних характеристик іншомовного тексту [15, с. 126]. Стратегії доместикащії і фороренізації можна назвати базовими стратегіями перекладу. Необхідно відзначити, що, основними характеристиками доместикації тексту є простота сприйняття і прозорість змісту тексту. Читач може простежити індивідуальність і цілі автора, а у реципіента створюеться враження, що він читає оригінал, а не переклад [7, с. 46]. Під час фроренізації текст може залишатися незрозумілим для читача, оскільки стратегія перекладу культурно забарвлених слів не передбачає пояснення іноземного слова, і тому перекладений текст сприймається реципієнтом саме як переклад [8, с. 341].

На сьогоднішній день не існуе єдиної класифрікації культурно маркованої лексики, тому культурно маркована лексика, закріплена за специфрічними елементами культури, близька поняттю «мовні реалії» традиційної лінгвістики. Р. П. Зорівчак пропонуе виокремлювати реаліїодночлени, реалії-полічлени, що має номінатив- 
ний характер, реалії-фрразеологізми [3, с. 78]. С. Влахов та С. Флорін пропонують розглянути класифікацію реалії під різними кутами зору, а зокрема - за предметною та місцевою ознаками (в залежності від національної та мовної приналежності).

Так, за предметними показниками дослідники пропонують виокремлювати:

1) Геоградрічні реалії: назви об'єктів топографіï, включаючи метеорологію, назви етнографічних об'єктів, пов'язаних 3 активністю людини: Themes, London, Alaska, Tennessee тощо [1, с. 45-48].

2) Етнографрічні реалії:

- Народне життя, їжа, одяг транспорт): kilt, Yorkshire pudding, tube;

- праця (люди трудового процесу, організація та механізм праці): undocumented alien (long-term US resident without either US citizenship or visa);

- мистецтво і культура (музичні інструменти, музичні твори, танці та ін.).

1. Етнічні об'екти (назви осіб за місцем проживання, клички (зазвичай гумористичні або кривдні).

2. Міри і гроші (розрахункові одиниці, просторічні назви): dollar, euro, cent.

3. Суспільно-політичні реалії:

- державний лад, діяльність і діячі (адміністративно-територіальні одинищі, населені пункти);

- національні та громадські партії (органи влади та носії влади).

4. Суспільно-політичне життя (державний лад, діяльність і діячі, національні та громадські партії, суспільні явища, посади, ступені, чини, звертання, навчальні заклади та культурні установи);

5. Військова зброя та звання (зброя, військовослужбовці і командири) [7, с. 54].

Культурно марковану лексику, зокрема, британізми в британських текстах розділяють на такі види:

1. Алюзивна лексика - культурно специфічні реалії побуту і життя британців, які не мають відповідностей на рівні концептів і лексичних відповідностей в інших мовах, наприклад: ерic banquets; The tabloids report that the epic banquets will take place from February 11-15. (Таблоїди повідолляють, що епічні бенкети відбуватилуться 311 по 15 лютого). Для українськомовних читачів в цьому випадку буде незрозумілим 2 терміни: tabloid - жовта преса, вид бульварної газети, яка виходить щоденно, вперше даний вид газети з'явився у Великобританії [6, с. 67]; epic banquets грандіозний банкет, званий обід або вечерю в урочистих ралках, шо влаштову еться на честь певної особи або подї. При перекладі буде доречно використати авторський коментар або застосувати описовий переклад для адекватної передачі інформації з мови оригіналу мовою перекладу.

2. Фонова лексика - слова, що збігаються за об'єктивним змістом у декількох мовах, але різняться за емощійно-естетичними асоціаціями [2, с. 126]. До фонової лексики можна віднести: топоніми (назви місцевості), антропоніми (власні назви), слова-символи (художні образи), слова, яким притаманні національні асоціації.

Термін «реалія» ще до введення у науковий дискурс поняття «культурно маркована лексика» вживався як його замінник.
У процесі перекладу з одніеї мови на іншу можна виявити певні закономірні розбіжності в області лексичного складу мови та граматичної будови. Значні труднощі при перекладі представляє явище безеквівалентності. Під безеквівалентною лексикою маються на увазі іншомовні слова і словосполучення, що позначають предмети, процеси і інші реалії життя, які на даному етапі не мають еквівалентів в мові перекладу [4, с. 47]. Повна неможливість знайти відповідність слову іноземної мови відбувається в тому випадку, коли слово оригіналу позначає чисто місцеве явище, якому немає відповідності в культурі іншого народу.

Виділяють такі основні труднощі передачі національно маркованої лексики при перекладі:

1) відсутність у мові перекладу еквівалента;

2) необхідність, разом з предметним значенням слова, передати і його колорит, його додатковий відтінок та специфічне забарвлення.

У сучасній теорії та практиці перекладу виділять такі способи перекладу культурно маркованої лексики: транскрипція і транслітерація, калькування, описовий, наближений, гіпонімічний, контекстуальний переклад та створення нового відповідника.

Транслітерація - запозичення іноземного слова, яке потім передають літерами мови перекладу, а в усному мовленні вимовляється згідно норм вимови мови перекладу. Чимало слів, утворені цим методом увійшло в мову перекладу. Elizabeth dispensed with the chauffeur to drive her Daimler Saloon. Єлизавета відпустила шоoбера і салиа водила свій Дайллер-салон [11, с. 53]. Daimler Saloon у наведеному прикладі виступає національно маркованою лексикою, що позначає вид британського авто представницького класу.

Транскрипція - побуквенна передача звучання слова іноземної мови графічними засобами мови перекладу 3 максимальним фонетичним наближенням до ㄲï оригінальної dорми. Наприклад, St. James's Street [11, с. 42] - СентДжеейлс-стріт.

Іноді способи транскрипщії і транслітерації можуть повністю або частково збігатися внаслідок їх деякого подібності. Перевагами ж џих способів перекладу $є$, перш за все, стислість і точність передачі необхідних реалій на іншу мову [14, с. 23-41]. Однак в тих випадках, коли власне ім'я не просто називає предмет, а має якесь додаткове значення, механічна передача звучання не забезпечує адекватності перекладу. Адекватність перекладу досягається тільки шляхом експлікації смислової структури.

Наступний прийом, який також широко використовується при передачі реалій калькування, тобто переклад лексичної одиниці, при якому iï складові частини буквально передаються за допомогою відповідних елементів в мові перекладу [14, с. 26-28]. Застосування цього способу може максимально зберегти семантику вихідної реалії, але не національного колориту. Слова, отримані за допомогою калькування можуть набути широкого поширення в мові, але при цьому залишатися іншомовними. Margaret Thatcher's decisiveness in prosecuting the Falklands War greatly enhanced her image as "the Iron Lady" [11, с. 310]. Твердість, проявлена Маргарет 
Тетчер в ході Фолклендськой калпанї, сильно зліинила її образ "залізної леді". В українській мові цей термін позначає сильну,впевнену в собі жінку,що здебільшого очолюе посаду керівника.

Описовий, або пояснювальний переклад використовуеться у випадках, коли немає можливості передати мовний елемент через його відсутність в мові перекладу. Основна перевага цього способу полягає в тому, що він здатний повно розкрити суть явища, виключаючи при цьому неповне розуміння читача, як може статися у випадку 3 калькуванням або транскрипцією. Однак описовий переклад має і ряд недоліків: він дуже багатослівний і в зв'язку з цим реалія часто перекладається не аналогічною за структурою одиницею іншої мови, а розгорнутим словосполученням або багатослівним описом. Elizabeth II presided over her first investiture [11, с. 228]. Слизавета II nриступила до першої своєї иеремонї̈ нагородження інвеститури. В цьому прикладі в тексті перекладу збережено прямий еквівалент слова "investiture», але разом 3 цим розширено значення даного слова в умовах контексту для кращого розуміння i сприйняття читачем. Варто додати, що описовий переклад дуже часто реалізуеться в тексті перекладу за допомогою використання перекладачем виносок або посилань в кінщі сторінки. Пояснення, представлені в них, допомагають всебічно розкрити значення реалії для українськомовного читача, не захаращуючи при цьому основний текст. Тож описовий переклад може повно розкрити сутність реалії, позначеного для читача незнайомій лексичної одиницею і тим самим допомогти перекладачеві в деяких складних ситуаціях для точної передачі явища чужої культури.

Прийоми створення нового слова використовуються тоді, коли недоцільно перекладати слово вище зазначеними способами, тому перекладач змушений ввести авторське слово для позначення терміна близького за змістом до мови оригіналу за допомогою засобів мови перекладу: le club "Le Chant du Slip" [12, с. 56]. - лебедина nicня.При цьому зберігаються смисловий зміст i форма лексеми мови джерела, а також національна та історична своєрідність [5, с. 64]. Згодом багато неологізмів освоюються і збагачують словниковий склад мови перекладу.

Наближений переклад. Під наближеним перекладом (переклад за допомогою аналога) розуміють використання лексичної одиниці іноземної мови, що лише частково збігається за значенням зі словами мови перекладу, оскільки українська та англійська мови мають відмінні особливості, а саме на морфологічному та синтаксичному рівнях, тому даний спосіб використовуеться вкрай рідко, адже за допомогою нього досить важко досягти адекватності перекладу. Snow Maiden Cнігуронька, muffin - здоба [12, с. 22].

Гіпонімічний переклад являе собою заміну видового поняття на родове, тобто передачу на- цінально маркованої лексики мовною одиницею, що має більш широке значення: diner [11, c. 34] забігайлівка - невелике кафбе без зручностей. Описаний метод перекладу дозволяе відмовитися від транскрипщії і зробити заміну понять, різниця між якими в умовах даного контексту незначна.

Контекстуальний переклад - заміна словникового відповідника при перекладі логічно пов'язаним 3 ним словом. В даному випадку основним оріентуванням перекладача служить контекст. Ілюстращією такого прийому може бути переклад фррази: "I'm sorry, but we do not have the dishes you have ordered" [12, с. 56]. "Вибачте, але ми не можело подати Вал ні консоме, ні проgбітролі, ні фбльоранси. Залінюють висловол: "У нас нелае італійськой кухні». Основним недоліком такого перекладу є повне зникнення реалії як носія певного національного колориту.

На сьогодні в наукових колах сучасної лінгвістики і лінгвокультурології спостерігається зростаючий інтерес до взаємозв'язку мови і культури в процесі дослідження труднощів, пов'язаних з перекладом культурно маркованої лексики.

Висновки 3 даного дослідження та перспективи. У результаті дослідження було виділено основні форми і методи роботи з культурно маркованої лексикою, класифіковані труднощі перекладу даної лексики. Аналіз видів культурно маркованої лексики показав, що найчастіше труднощі при перекладі виникають під час передачі алюзій і фонової лексики рідною мовою.

При перекладі англійською мовою культурно маркованої лексики стратегія доместикації використовується в три рази частіше ніж стратегія форенізаціі. Метод доместикації дозволяе співставити вихідні концепти слів. Стратегія форенізації має протилежну мету - збереження оригінальності в культурній коннотації вихідної культури. Таким чином, культурно маркована лексика виступає як свого роду «хранитель» і «носій» країнознавчої інформації. Крім того, вона розширюе і збагачуе лінгвістичні знання. Тому перекладачеві, що пращює в сорері крос-культурної комунікації, необхідно мати міжкультурні компетенції, одним 3 компонентів якої є культурно маркована лексика, яка дозволяє мовній особистості вийти за межі власної культури.

У цілому, переклад культурно маркованої лексики являе собою збірний та складний процес, який вимагає від перекладача відмінного знання мови та високого рівня лінгвокультурної підготовки.

Переклад 3 англійської мови українською представляє певні труднощі для перекладача, так як дана робота вимагає не тільки знання мови, але і знання менталітету, культури країни, великого перекладацького досвіду та розмовних виразів.

Подальші дослідження слід спрямувати на вивчення питання перекладу культурно маркованої лексики в суспільно-політичному дискурсі.

\section{Список літератури:}

1. Влахов С., Флорин С. Непереводимое в переводе. Москва : Международные отношения, 1980. С. $18-93$.

2. Зорівчак Р.П. Реалія в художньому мовленні: перекладознавчий аспект. Львів : Іноземна фрілологія, 1994. $286 \mathrm{c}$

3. Зорівчак Р.П. Реалія і переклад. Львів : Вид-во при Львівському держ. ун-ті, 1989. 215 с.

4. Зорівчак Р.П. Реалія як компонент національно-культурного контексту: перекладознавчий аспект. Славянские языки в свете культуры : сборник научн. статей. Москва : ООО «Темп», 2006. С. 27-49. 
5. Зорівчак Р.П. Статус реалії як перекладознавчого терміна. Київ : А.С.К., 1985. 164 с.

6. Таблоїд // Літературознавча енциклопедія: у 2 т. / авт.-уклад. Ю.І. Ковалів. Київ : ВЦ «Академія», 2007. T. 2: M Я. 455 c.

7. Goodspeed E.J. Problems of New Testament Translation. Chicago, Univ. Chicago Press, 2015. 180 p.

8. Newmark P. Approaches to translation. Oxford : Prentice Hall, 1981. 200 p.

9. Newmark P. Approaches to translation. Oxford, 2015. $301 \mathrm{p}$.

10. Savory T. The Art of Translation. L., 2017. 420 p.

11. Smith S.B. Elizabeth the Queen: The Life of a Modern Monarch. New York: Random House, 2012. 505 p.

12. Traylor Steven. Right Around TheCorner. iUniverse, Inc.; Edited ed. Edition. April 27, 2004. 228 p.

13. Venuti L. The Translator's Invisibility: A History of Translation. London \& New York : Routledge, 1995.353 p.

14. Venuti L. Translation, community, utopia // The Translation Studies Reader / Ed. by Lawrence Venuti. Taylor \& Francis, 2004. Pp. 468-488.

15. Vetrinskaya V.V., DmitrenkoT.A. (2017). Developing students' sociocultural competence in foreign language classes. Training language and culture, vol. 1, issue 2, pp. 23-41.

\section{References:}

1. Vlakhov S., Florin S. (1980). Neperevodimoe v perevode [Untranslatable in translation]. Moskva: Mezhdunarodnye otnosheniya.

2. Zorivchak R.P. (1994). Realiia v khudozhnomu movlenni: perekladoznavchyi aspekt [Reality in artistic speech: the translation aspect]. Lviv: Inozemna filolohiia.

3. Zorivchak R.P. (1989). Realiia i pereklad [Reality and translation]. Lviv: Vyd-vo pry Lvivskomu derzh. un-ti.

4. Zorivchak R.P. (2006). Realiia yak komponent natsionalno-kulturnoho kontekstu: perekladoznavchyi aspect [Reality as a component of the national-cultural context: the translation aspect]. Slavyanskie yazyki $v$ svete kul'tury: sbornik nauchn. statey. Moskva: OOO “Temp".

5. Zorivchak R.P. (1985). Status realii yak perekladoznavchoho termina [The status of reality as a translation term]. Kyiv: A.S.K.

6. Tabloid // Literaturoznavcha entsyklopediia (2007). [Literary encyclopedia]: u 2 t. / avt.-uklad. Yu.I. Kovaliv. Kyiv: VTs "Akademiia". T. 2: M Ya.

7. Goodspeed E.J. (2015). Problems of New Testament Translation. Chicago: Univ. Chicago Press.

8. Newmark P. (1981). Approaches to translation. Oxford: Prentice Hall.

9. Newmark P. (2015). Approaches to translation. Oxford.

10. Savory T. (2017). The Art of Translation. L.

11. Smith S.B. (2012). Elizabeth the Queen: The Life of a Modern Monarch. New York: Random House.

12. Traylor Steven (2004). Right Around TheCorner. iUniverse, Inc.; Edited ed. Edition.

13. Venuti L. (1995). The Translator's Invisibility: A History of Translation. London \& New York: Routledge.

14. Venuti L. (2004). Translation, community, utopia // The Translation Studies Reader / Ed. by Lawrence Venuti. Taylor \& Francis.

15. Vetrinskaya V.V., Dmitrenko T.A. (2017). Developing students' sociocultural competence in foreign language classes. Training language and culture. 